Biogeosciences Discuss., doi:10.5194/bg-2017-129, 2017

Manuscript under review for journal Biogeosciences

Discussion started: 19 May 2017

(c) Author(s) 2017. CC-BY 3.0 License.

\title{
Organic exudates promote Fe(II) oxidation in Fe limited cultures of Trichodesmium erythraeum
}

\author{
Hanieh T. Farid ${ }^{1 *}$, Kai G. Schulz ${ }^{2}$ and Andrew L. Rose ${ }^{1,3}$
}

${ }^{1}$ Southern Cross Geoscience, Southern Cross University, Lismore 2480, Australia

*Corresponding author email address: hanieh.farid@scu.edu.au

${ }^{2}$ Centre for Coastal Biogeochemistry, School of Environment, Science and Engineering, Southern Cross University, Lismore NSW, 2480, Australia

${ }^{3}$ School of Environment, Science and Engineering, Southern Cross University, Lismore, NSW, 2480, Australia

\begin{abstract}
.
A luminol chemiluminescence method was employed to study the oxidation kinetics of $\mathrm{Fe}$ (II) in both the absence and the presence of organic exudates released by the marine cyanobacterium Trichodesmium erythraeum. The apparent Fe(II) oxidation rate constant was studied for batch cultures grown with varying $\mathrm{Fe}^{\prime}$ concentrations of 0.05-0.29 and 1.44-2.03 $\mathrm{nmol} \mathrm{L}^{-1}$ at $\mathrm{pH}$ ranges from 8.1-8.6, corresponding to the change in $\mathrm{pH}$ in the cultures during the entire growth cycle. Fe(II) oxidation was accelerated when cells were growing exponentially and gradually decreased towards the stationary phase, consistent with the presence of organic exudates. The best fit of the kinetic model to the data also demonstrated clear differences in apparent $\mathrm{Fe}$ (II) oxidation rate constants during different growth phases. However, no significant difference was observed in oxidation rate constants between the two $\mathrm{Fe}^{\prime}$ treatments. These findings suggest that Trichodesmium releases organic compounds into the extracellular environment that influence $\mathrm{Fe}$ redox chemistry, potentially affecting $\mathrm{Fe}$ bioavailability, and that the nature of the $\mathrm{Fe}(\mathrm{II})$ complexes formed is not influenced by $\mathrm{Fe}$ limitation of the organism's growth.
\end{abstract}




\section{Introduction}

While photosynthetic algae are considered to be the main source of dissolved organic matter (DOM) in the ocean, the production rate and its molecular composition can vary, depending on the cellular growth phase (Myklestad, 2000). In exponentially-growing cells the composition of DOM exudates shifts from proteins towards carbohydrates when approaching nutrient limitation and reaching the stationary phase (Myklestad, 2000). An increase in cellular DOM exudation rate with decreasing nutrient availability is an important metabolic strategy to dissipate excess light energy during nutrient starvation (Myklestad, 2000). The release of DOM has been also suggested as a strategy to regulate the speciation, bioavailability and toxicity of trace metals in the external milieu (Jones, 1998;Moffett and Zafiriou, 1990).

Iron $(\mathrm{Fe})$ is an essential trace metal and micronutrient for all phytoplankton and thought to limit primary production in up to $40 \%$ of the oceans (Falkowski et al., 1998). Fe limitation negatively impacts photosynthetic and respiratory performance, and enzymatic processes in all phytoplankton (Geider 1999). Diazotrophic cyanobacteria suffer additional consequences from Fe limitation, which negatively influences their $\mathrm{N}_{2}$ fixation activity (Berman-Frank et al., 2003). Marine bacteria are known to release strong iron-binding ligands (e.g. siderophores, which are low-molecular-weight Fe binding molecules specifically excreted by organisms for Fe acquisition) and/or weak iron-binding ligands (e.g. polysaccharides) under Fe-deficient conditions (Ito and Butler, 2005;Sohm et al., 2011). However, to the best of our knowledge, no systematic study has yet been performed on how cyanobacterial exudates may influence Fe chemistry during the various growth phases.

In marine surface waters, $\mathrm{Fe}$ exists in two oxidation states (Fe(II) and $\mathrm{Fe}(\mathrm{III})$ ), and is mostly (up to 99\%) complexed with organic ligands (L) (Hutchins et al., 1999;Nolting et al., 1998;Völker and Wolf-Gladrow, 1999). While unchelated forms of Fe, and especially unchelated forms of $\mathrm{Fe}$ (III) (typically denoted Fe(III)'), are assumed to constitute the most bioavailable pool in oxygenated seawater, dissociation of organic Fe complexes (FeL) is usually a precursor step in Fe supply to microorganisms (Fujii et al., 2010a). While Fe(III) typically forms relatively strong complexes with organic compounds, $\mathrm{Fe}(\mathrm{II}) \mathrm{L}$ complexes are typically much more labile, and thereby constitute a more bioavailable pool under the same physicochemical conditions (Morel et al., 2008;Shaked et al., 2005). However, the slightly alkaline and oxygenated conditions typical of seawater, $\mathrm{Fe}(\mathrm{II})$ is rapidly oxidised to the more dominant and thermodynamically stable Fe(III). While some studies have found Fe(III) reduction to be a prerequisite for Fe acquisition by microorganisms (Fujii et al., 2010b;Morel et al., 2008; Rose et al., 2005;Salmon et al., 2006; Shaked et al., 2005), oxidation of Fe(II) to $\mathrm{Fe}$ (III) has been also reported in a few eukaryotic microorganisms prior to uptake (Garg et al., 2007; Maldonado et al., 2006). This poses challenges for understanding the role of $\mathrm{Fe}(\mathrm{II})$ in the Fe nutrition of phytoplankton, as the ultimate source of Fe for phytoplankton uptake is still subject to debate.

Trichodesmium erythraeum, a globally significant diazotrophic cyanobacterium, has shown an intriguing variation in Fe acquisition mechanisms, depending upon the potentially available $\mathrm{Fe}$ species (Roe and Barbeau, 2014;Rubin et al., 2011). For instance, Roe et al. (2012) reported a higher propensity for the cultured strain IMS101 to acquire inorganic Fe (including both Fe(II) and $\mathrm{Fe}(\mathrm{III})$ ) and $\mathrm{Fe}$ (III) that was weakly bound to organic ligands than Fe bound in $\mathrm{Fe}(\mathrm{III})$ - 
siderophore complexes. This finding was in accordance with previous reports on the existence of some homologous genes to an $\mathrm{ABC}$-type $\mathrm{Fe}^{3+}$ transporter within the genome in the absence of membrane receptor proteins for $\mathrm{Fe}(\mathrm{III})$-siderophore complexes (Chappell and Webb, 2010; Webb et al., 2001). Roe and Barbeau (2014) also found a higher Fe uptake rate by $T$. erythraeum IMS101 in cultures containing $\mathrm{Fe}(\mathrm{III})$-citrate compared to inorganic $\mathrm{FeCl}_{3}$ and $\mathrm{Fe}(\mathrm{II})$-citrate. Rubin et al. (2011) showed that Trichodesmium colonies can actively increase the dissolution and acquisition of Fe from particulate sources such as dust. The release of superoxide $\left(\mathrm{O}_{2}^{--}\right)$(Godrant et al., 2009) and exopolysaccharides (EPS) into the extracellular surroundings by IMS101 under Fe stress conditions have also been reported (Berman-Frank et al., 2007). However, while numerous studies focusing on $\mathrm{O}_{2}^{--}$as potential $\mathrm{Fe}$ reducing agent in the extracellular milieu and its role in Fe uptake rates in cyanobacteria (Fujii et al., 2010a;Godrant et al., 2009;Kranzler et al., 2011;Roe et al., 2012;Rose, 2005), very few studies have examined effect of organic exudates from cyanobacteria on Fe redox chemistry. FeL complexation reactions, as well as the reaction of inorganic and organically bound $\mathrm{Fe}(\mathrm{II})$ with oxygen, are crucial regulators of the bioavailability of $\mathrm{Fe}$ in ambient seawater (Rose and Waite, 2002). While the exact role of organic complexation is not yet clear, retardation and acceleration of $\mathrm{Fe}$ (II) oxidation rates have both been observed depending upon the type of organic compound (Rose and Waite, 2003;Santana-Casiano et al., 2000) and/or physicochemical conditions (Gonzalez et al., 2014;Jobin and Ghosh, 1972; Liang et al., 1993). Saccharides, amino acids and phenolic compounds are the major phytoplankton exudates which have so far been characterised to form weak complexes with inorganic Fe species (Benner, 2011;Hassler et al., 2011;Santana-Casiano et al., 2014), most likely with Fe(III) (Elhabiri et al., 2007; Santana-Casiano et al., 2010). In contrast to $\mathrm{O}_{2}^{--}$, which can influence $\mathrm{Fe}$ uptake rates by reducing $\mathrm{Fe}(\mathrm{III})$ species (Rose, 2012;Rose et al., 2005), the formation of complexes with weak Fe-binding ligands might be also beneficial for $\mathrm{Fe}$ uptake by Trichodesmium via a non-reductive ligand exchange mechanism (Roe and Barbeau, 2014). Given these gaps about the role of organic exudates from cyanobacteria in Fe nutrition, this study aimed to address the following questions:

(i) How do organic exudates released in a batch culture of the marine cyanobacterium $T$. erythraeum influence $\mathrm{Fe}(\mathrm{II})$ oxidation rates?

(ii) Does this influence depend on the Fe nutritional status and growth phase of the organism?

In an attempt to answer the questions above, two cultures of $T$. erythraeum were established under conditions corresponding to varying $\mathrm{Fe}$ bioavailability using different ethylenediaminetetraacetic acid (EDTA) concentrations. Subsequently, a FeLume system (Emmenegger et al., 1998;King et al., 1995) was employed to investigate the oxidation kinetics of nanomolar concentrations of $\mathrm{Fe}(\mathrm{II})$ by $\mathrm{O}_{2}$ in the presence of organic exudates released during the various growth phases.

\section{Materials and methods 2.1 Reagents and solutions}

A $2 \mathrm{mmol} \mathrm{L}^{-1}$ EDTA ( $\mathrm{Na}_{2}$ EDTA. $2 \mathrm{H}_{2} \mathrm{O}$, Ajax Finechem Pty Ltd) stock solution was prepared by dissolving $0.0745 \mathrm{~g}$ in $100 \mathrm{~mL}$ of high purity Milli-Q water (18.2 M $\Omega . \mathrm{cm}$ resistivity from a Milli-Q Academic Water Purification System, installed in a clean room equipped with a HEPA 
filter, hereafter denoted as HPMQ). A $500 \mu \mathrm{mol} \mathrm{L}^{-1}$ stock solution of '(III) was prepared by dissolving $13.5 \mathrm{mg}$ of $\mathrm{FeCl}_{3} .6 \mathrm{H}_{2} \mathrm{O}$ (Sigma-Aldrich) in $100 \mathrm{~mL}$ of HPMQ that heen acidified with $100 \mu \mathrm{L}$ of $1 \mathrm{~mol} \mathrm{~L}^{-1} \mathrm{HCl}$ (prepared from 34-37\% w/w HCl, Instrument Quality, Seastar Chemicals Inc, hereafter denoted as trace metal grade acid).

A $4 \mathrm{mmol} \mathrm{L}^{-1}$ stock solution of $\mathrm{Fe}$ (II) was prepared by dissolving $157 \mathrm{mg}$ of ammonium iron(II) sulfate hexahydrate $\left(\mathrm{Fe}\left(\mathrm{NH}_{4}\right)_{2}\left(\mathrm{SO}_{4}\right)_{2} \cdot 6 \mathrm{H}_{2} \mathrm{O}\right.$, Ajax Finechem Pty Ltd, reagent grade) in $100 \mathrm{~mL}$ of HPMQ. The stock solution was stabilised by adding $20 \mu \mathrm{L}$ of $6 \mathrm{~mol} \mathrm{~L}^{-1}$ trace metal grade acid (Rose and Waite, 2003). The stock solution was then stored in an acid-cleaned polypropylene bottle and kept in the dark (wrapped in aluminium foil) at $4^{\circ} \mathrm{C}$ when not in use (Rose and Waite, 2003). To facilitate preparation of standards at nanomolar $\mathrm{Fe}$ (II) concentrations, a fresh $1 \mu \mathrm{mol} \mathrm{L}-1 \mathrm{Fe}$ (II) solution was prepared daily by adding $25 \mu \mathrm{L} \mathrm{Fe}$ (II) stock solution $\left(4 \mathrm{mmol} \mathrm{L}^{-1}\right)$ to $100 \mathrm{~mL}$ of HPMQ. The $\mathrm{pH}$ in the secondary stock solution was low enough to prevent oxidation of Fe(II) for one day but sufficiently high that it did not cause notable change in $\mathrm{pH}$ after addition to the samples. A portable meter (Hach HQ11D) was used to monitor $\mathrm{pH}$ in the solutions and was calibrated using standard $\mathrm{pH}$ buffers on the NBS scale (pH 4.00, 7.00 and 10.00 at $20^{\circ} \mathrm{C}$ ).

A $0.5 \mathrm{mmol} \mathrm{L}{ }^{-1}$ luminol reagent was prepared in $1 \mathrm{~mol} \mathrm{~L}^{-1}$ ammonium hydroxide solution $\left(\mathrm{NH}_{4} \mathrm{OH}\right.$ ) by dissolving $89 \mathrm{mg}$ of luminol (5-Amino-2,3-dihydro-1,4-phthalazinedione, SigmaAldrich) in $69 \mathrm{~mL} \mathrm{NH}_{4} \mathrm{OH}$ solution (28-30\% w/w, Sigma-Aldrich) and adding HPMQ to adjust the final volume to $1 \mathrm{~L}$ using a volumetric flask (Rose and Waite, 2002). The regent then was adjusted to $\mathrm{pH} 10.3$ by adding $26 \mathrm{~mL}$ of $6 \mathrm{~mol} \mathrm{~L}^{-1}$ trace metal grade acid and stored in the dark at room temperature for at least $24 \mathrm{~h}$ before use (Rose and Waite, 2003).

\subsection{Culture conditions}

A non-axenic unialgal strain of T. erythraeum IMS101 was obtained from the National Centre for Marine Algae and Microbiota (NMCA, USA) and to minimize the occurrence of undesired organisms in significant numbers, the stock cultures were always kept in exponential phase using a semi-continuous approach. No obvious microscopic changes (e.g. bacterial colony formation) were observed in the cultures during experiments, however there was no definitive evidence for the absolute absence of heterotrophic bacteria, whose potential presence must therefore be considered when interpreting the results. Stock cultures were grown in $2.5 \mathrm{~L}$ polycarbonate bottles (acid-washed and sterilised) containing YBC-II medium (hereafter denoted as artificial seawater, ASW) prepared according to the recipe given in Andersen (2005) but modified to contain $10 \mathrm{nmol} \mathrm{L}^{-1} \mathrm{FeCl}_{3}, 2 \mu \mathrm{mol} \mathrm{L}^{-1} \mathrm{KH}_{2} \mathrm{PO}_{4}, 2.1 \mathrm{mmol} \mathrm{L}^{-1}$ of $\mathrm{NaHCO}_{3}$ and different EDTA concentrations as described below. To minimise the possibility of metal and biological contamination, the ASW was stored with a few $\mathrm{mL}$ of purified Chelex-100 resin (Sunda et al., 2005) for at least $24 \mathrm{~h}$ and filtered through a sterile $0.2 \mu \mathrm{m}$ polycap TC filter capsule (polyethersulfone membrane (PES), Whatman) before the addition of nutrient solutions (including trace metals, phosphorus and vitamins).

Different levels of Fe bioavailability were established by adding either $50 \mathrm{nmol} \mathrm{L}^{-1}$ or $20 \mu \mathrm{mol}$ $\mathrm{L}^{-1}$ EDTA at a constant $\mathrm{Fe}$ (III) concentration of $10 \mathrm{nmol} \mathrm{L}^{-1}$. The latter was achieved by adding $20 \mu \mathrm{L}$ of the $500 \mu \mathrm{mol} \mathrm{L}^{-1} \mathrm{Fe}(\mathrm{III})$ stock solution per litre of ASW and allowing to equilibrate for $1 \mathrm{~h}$. The concentration of unchelated iron ([Fe']) in the seawater was calculated from total $\mathrm{Fe}(\mathrm{III})$ and EDTA concentrations using an equilibrium complexation model described in 
Schulz et al. (2004) at a pH range from 8.1 to 8.6 corresponding to the range of $\mathrm{pH}$ values measured in cultures (Table 1). All pH measurements were conducted on the NBS scale and assumed to equal the $\mathrm{pH}$ on the free hydrogen ion scale to within an uncertainty of $0.005 \mathrm{pH}$ units (Lewis et al., 1998). This error is negligible for the purposes of this study. The $\mathrm{Fe}$ complexation model accounts for complexes of $\mathrm{Fe}$ (III) with $\mathrm{Cl}^{-}, \mathrm{F}^{-}, \mathrm{SO}_{4}^{2-}$ and the $\mathrm{Fe}(\mathrm{III}) \mathrm{OH}$ species, as well as protonated or complexed forms of EDTA with $\mathrm{Fe}^{3+}, \mathrm{Cu}^{2+}, \mathrm{Co}^{2+}, \mathrm{Mn}^{2+}, \mathrm{Zn}^{2+}$, $\mathrm{Ca}^{2+}$ and $\mathrm{Mg}^{2+}$.

Table 1. Calculated concentrations of total $\mathrm{Fe}$ ([FeT]), unchelated $\mathrm{Fe}$ ([Fe']), organically complexed $\mathrm{Fe}([\mathrm{FeL}])$ and precipitated $\mathrm{Fe}([\mathrm{Fe}(\mathrm{s})])$ in the presence of different EDTA concentrations and a total $\mathrm{Fe}(\mathrm{III})$ addition of $10 \mathrm{nM}$.

\begin{tabular}{ccccc}
\hline $\begin{array}{c}\text { EDTA } \\
\left(\mu \mathrm{mol} \mathrm{L}^{-1}\right)\end{array}$ & $\begin{array}{c}{[\mathrm{FeT}]} \\
\left(\mathrm{nmol} \mathrm{L}{ }^{-1}\right)\end{array}$ & $\begin{array}{c}{\left[\mathrm{Fe}^{\prime}\right]} \\
\left(\mathrm{nmol} \mathrm{L}^{-1}\right)^{\mathrm{a}}\end{array}$ & $\begin{array}{c}\mathrm{FeL} \\
\left(\mathrm{nmol} \mathrm{L}^{-1}\right)\end{array}$ & $\begin{array}{c}{[\mathrm{Fe}(\mathrm{s})]} \\
\left(\mathrm{nmol} \mathrm{L}^{-1}\right)\end{array}$ \\
\hline 0.05 & 10 & $1.44-2.03$ & $0.01-0.05$ & $8.51-7.96$ \\
20 & 10 & $0.05-0.29$ & $9.7-9.95$ & 0
\end{tabular}

$\overline{{ }^{a}} \mathrm{Fe}^{\prime}$ concentrations are reported as a range corresponding to $\mathrm{pH}$ varying from 8.1-8.6, representing the change in $\mathrm{pH}$ in the culture during the entire growth cycle.

Culture media were inoculated with exponentially growing cells at a starting concentration of about $500 \mathrm{cell} / \mathrm{mL}$ and incubated at $27^{\circ} \mathrm{C}$, with a photon flux density of $110 \mu$ mol quanta $\mathrm{m}^{-2}$ $\mathrm{s}^{-1}$ (measured with a LI-193 Spherical Quantum Sensor, LiCor) under a 14:10 dark/light cycle. Exponentially growing cells were inoculated three times into fresh media over $24 \mathrm{~d}$ and acclimated to the experimental conditions for about 12 generations. To monitor growth in the cultures, $5 \mathrm{~mL}$ aliquots were taken every 2 days fixed in Lugol iodine solution (1\%) and then analysed for cell numbers using an automated particle imaging system (Morphologi G3, Malvern Instruments, UK) (see Sect. S1.1 in Supplementary Material for more details).

\subsection{Experimental $\mathrm{Fe}$ (II) oxidation and analytical procedures}

To examine Fe(II) oxidation rates throughout the growth cycle in the batch cultures, about 250 $\mathrm{mL}$ of each culture was harvested every $2 \mathrm{~d}$ and adjusted to $\mathrm{pH} 8.0$ by the dropwise addition of $1 \mathrm{~mol} \mathrm{~L}^{-1}$ trace metal grade acid while the sample was maintained at $20 \pm 1^{\circ} \mathrm{C}$ in a water bath (Grant OLS 200). Subsequently, samples were gently filtered by gravity through an acid cleaned $5 \mu \mathrm{m}$ filter (47 mm, PC, Whatman) immediately before measurements. Given an average width of $\geq 20 \mu \mathrm{m}$ for each filaments, the filter pore size was considered small enough to prevent trichomes passing into the solution, however since the cultures were not axenic it is possible that some bacteria were present in the filtrate.

$\mathrm{Fe}$ (II) oxidation experiments were conducted by additions of appropriate volumes of a $1 \mu \mathrm{mol}$ $\mathrm{L}^{-1} \mathrm{Fe}$ (II) stock solution to give final concentrations of 5, 10 and $20 \mathrm{nmol} \mathrm{L}^{-1} \mathrm{Fe}$ (II) in $15 \mathrm{~mL}$ aliquots of filtered samples. At a salinity of 35 and at $20^{\circ} \mathrm{C}$ the $\mathrm{O}_{2}$ concentration in the samples was calculated to be $0.225 \mathrm{mmol} \mathrm{L}^{-1}$ (Garcia and Gordon, 1992), assuming $100 \%$ saturation at continuous stirring at $120 \mathrm{rpm}$ using an acid cleaned Teflon-coated magnetic stirrer during the entire experiment (Rose and Waite, 2002). The changes in [Fe(II) $\mathrm{T}]$ (the sum of both inorganic 
and organically complexed $\mathrm{Fe}$ (II) concentrations) over time were monitored by an automated continuous chemiluminescence flow system (Rose and Waite, 2002). The system is based on the reaction of the added $\mathrm{Fe}(\mathrm{II})$ with $\mathrm{O}_{2}$ and luminol reagent at high $\mathrm{pH}$ (Rose and Waite, 2001, 2002). Sample and the reagent are mixed in a spiral-shaped flow cell positioned beneath a photomultiplier tube (PMT) using a peristaltic pump at a flow of $1 \mathrm{~mL} / \mathrm{min}$ (Rose and Waite, 2002). The reaction results in the production of chemiluminescence at $426 \mathrm{~nm}$. The emitted photons were recorded over a fixed time period of $600 \mathrm{~s}$ at one second integrals.

To account for potential effects of EDTA or other components of the culture media on $\mathrm{Fe}$ (II) oxidation rates, two different blank treatments (i.e. without $\mathrm{Fe}(\mathrm{II})$ additions) were analysed for baseline correction in the samples: (i) ASW containing the same nutrient (i.e. vitamins, trace metals, $\mathrm{FeCl}_{3}$ and phosphorus) and EDTA concentrations as in the culture samples, which provides the background signal in the absence of organic exudates; and (ii) culture samples which were filtered at least about $5 \mathrm{~h}$ prior to analysis and kept in the dark (wrapped in aluminium foil) to ensure that all pre-existing $\mathrm{Fe}(\mathrm{II}) / \mathrm{Fe}(\mathrm{II}) \mathrm{L}$ species were fully oxidised. The first set of blank values were used as an indicator of Fe(II) oxidation rate in the absence of organic exudates, while the second set of blank values were subtracted from filtrate samples after $\mathrm{Fe}(\mathrm{II})$ additions.

The system was calibrated directly with the experimental data based on the additions of known amounts of $\mathrm{Fe}$ (II) (yielding 5, 10 and $20 \mathrm{nmol} \mathrm{L}^{-1}$ ) to the samples in each experiment. All measurements were performed in duplicate and then the highest and lowest calculated rate constants were removed from each data set, leaving four replicates. Mean values were then considered for data analysis. The FeLume signals were related to Fe(II) concentrations by a power law calibration relationship, which was developed as follows. In the continuous flow system, the first reliable measurements of $\mathrm{Fe}(\mathrm{II})$ concentration cannot be made until about 70 $\mathrm{s}$ after adding $\mathrm{Fe}$ (II) to the sample due to the delay in mixing the sample with the reagent. During this time, a substantial proportion of the added Fe(II) may oxidise. Thus, to calculate initial Fe(II) concentrations at time zero, the data points obtained under steady flow conditions (70-600 s) were extrapolated back to the time at which Fe(II) was added to the samples via linear regression of the signal logarithm versus time (see Sect. S1.3 for details) (Rose and Waite, 2003). As the signal to noise ratio decreased towards the end of measurements, only data collected in the interval of 110-530 s after adding Fe(II) was used for kinetic analysis. Calibration curves were prepared by plotting the added $\log [\mathrm{Fe}(\mathrm{II})]$ versus the extrapolated log (signal), and a linear trend $\left(R^{2} \geq 0.9\right)$ on the $\log -\log$ plot (i.e. a power law function) was observed in all cases. The detection limit was about $0.5 \mathrm{nmol} \mathrm{L}^{-1}$ based on three times the calculated $\mathrm{Fe}$ (II) concentrations in the blanks.

\subsection{Analysis of $\mathrm{Fe}(\mathrm{II})$ oxidation kinetics}

For analysis of $\mathrm{Fe}$ (II) oxidation kinetics, it was assumed that $\mathrm{Fe}(\mathrm{II})$ is mainly oxidised by $\mathrm{O}_{2}$ due to its presence at a much higher concentration than other potential oxidants such as reactive oxygen species. This is a reasonable assumption given that with the relatively low (at most 20 nmol L-1) $\mathrm{Fe}(\mathrm{II})$ concentrations used, at most $10 \mathrm{nmol} \mathrm{L}^{-1} \mathrm{O}_{2}^{--}$and at most $5 \mathrm{nmol} \mathrm{L}{ }^{-1} \mathrm{H}_{2} \mathrm{O}_{2}$ could potentially accumulate due to reaction of $\mathrm{Fe}$ (II) with $\mathrm{O}_{2}$, and that previous studies have shown that the contribution of these species to $\mathrm{Fe}(\mathrm{II})$ oxidation under similar conditions is negligible (Rose and Waite, 2002). Moreover, the rate constants for reaction between $\mathrm{H}_{2} \mathrm{O}_{2}$ and 
Biogeosciences Discuss., doi:10.5194/bg-2017-129, 2017

Manuscript under review for journal Biogeosciences

Discussion started: 19 May 2017

(c) Author(s) 2017. CC-BY 3.0 License.

$\mathrm{Fe}$ (II)EDTA, as well as between $\mathrm{H}_{2} \mathrm{O}_{2}$ and other organic $\mathrm{Fe}(\mathrm{II})$ complexes, are orders of magnitude less than the rate constant for reaction between $\mathrm{H}_{2} \mathrm{O}_{2}$ and inorganic $\mathrm{Fe}$ (II) (Miller et al. 2009; Miller et al. 2016). This means that micromolar concentrations of $\mathrm{H}_{2} \mathrm{O}_{2}$ are needed to outcompete $\mathrm{O}_{2}$ and affect the oxidation rate; therefore only the reaction between $\mathrm{Fe}(\mathrm{II})$ and $\mathrm{O}_{2}$ was assumed to be important here. The kinetics of the reaction of $\mathrm{Fe}(\mathrm{II})$ with $\mathrm{O}_{2}$ are given by:

$\frac{\mathrm{d}[\mathrm{Fe}(\mathrm{II})]}{\mathrm{d} t}=-k[\mathrm{Fe}(\mathrm{II})]\left[\mathrm{O}_{2}\right]$

Eq. (1)

where $k$ is a second order rate constant for the reaction involving the two species $\mathrm{Fe}$ (II) and $\mathrm{O}_{2}$. However, since $\mathrm{O}_{2}$ was present at much higher concentration than $\mathrm{Fe}(\mathrm{II})$ under our experimental conditions, its concentration can be considered constant. Thus letting
$k^{\prime}=k\left[\mathrm{O}_{2}\right]$
Eq. (2)

Then Eq. (1) can be written in the form of a first order reaction, where $k^{\prime}$ represents a pseudofirst order rate constant:
$\frac{\mathrm{d}[\mathrm{Fe}(\mathrm{II})]}{\mathrm{d} t}=-k^{\prime}[\mathrm{Fe}(\mathrm{II})]$
Eq. (3)

Moreover, since the rate constants were all calculated based on observed overall reaction, hereafter $k^{\prime}$ is referred to "apparent" pseudo-first order rate constant.

The solution to equation 3 is:

$[\mathrm{Fe}(\mathrm{II})]=[\mathrm{Fe}(\mathrm{II})]_{0} e^{-k^{\prime} t}$

which can also be written as:

$\ln ([\mathrm{Fe}(\mathrm{II})])=\ln \left([\mathrm{Fe}(\mathrm{II})]_{0}\right)-k^{\prime} t \quad$ Eq. (5)

where $[\mathrm{Fe}(\mathrm{II})]_{0}$ is the initial $\mathrm{Fe}(\mathrm{II})$ concentration. The pseudo-first order rate constant can therefore be determined from linear regression of $\ln [\mathrm{Fe}(\mathrm{II})]$ against time.

While this approach has shown to be suitable for analysing oxidation of inorganic Fe(II), the presence of organic ligands may result in non-pseudo first order kinetics due to formation of organic $\mathrm{Fe}$ (II) complexes followed by the parallel oxidation of inorganic Fe(II) and organically complexed Fe(II). Since the oxidation of Fe(II) could also be affected by EDTA, a three-step kinetic modelling approach was employed using the software Kintek Explorer. The steps were:

(i) The oxidation of inorganic Fe(II) was modelled in the absence of any organic compounds, which allowed determination of the rate constant for the reaction between $\mathrm{Fe}(\mathrm{II})$ and $\mathrm{O}_{2}$ in ASW matrix.

(ii) Considering two more reactions, namely the complexation of $\mathrm{Fe}(\mathrm{II})$ by EDTA and subsequent oxidation of the $\mathrm{Fe}$ (II)EDTA complex by $\mathrm{O}_{2}$, which allowed determination of the oxidation rate constant for the Fe(II)EDTA complex in ASW; and

(iii) The addition of two more reactions accounting for $\mathrm{Fe}(\mathrm{II}) \mathrm{L}$ complexation with organic matter and its subsequent oxidation by $\mathrm{O}_{2}$. The assumptions for organically $\mathrm{Fe}$ complexation and oxidation rate constants are described further in the results and discussion. 
Biogeosciences Discuss., doi:10.5194/bg-2017-129, 2017

Manuscript under review for journal Biogeosciences

Discussion started: 19 May 2017

(C) Author(s) 2017. CC-BY 3.0 License.

\section{Results and discussion}

\subsection{Growth rates in the cultures}

The culture containing a lower Fe' concentration exhibited a lower growth rate $(p \leq 0.05)$ than the culture with a higher $\mathrm{Fe}^{\prime}$ concentration (Fig. 1). However, the biomass carrying capacity for the culture containing higher EDTA concentration was considerably higher, despite the lower $\mathrm{Fe}^{\prime}$ concentration, due to the absence of Fe precipitation in this culture. Comparing the values obtained in this study with other studies shows that the growth rates are within the range previously reported for Fe-limited conditions for this microorganism (Berman-Frank et al., 2001;Chappell and Webb, 2010;Kustka et al., 2003;Shi et al., 2012).

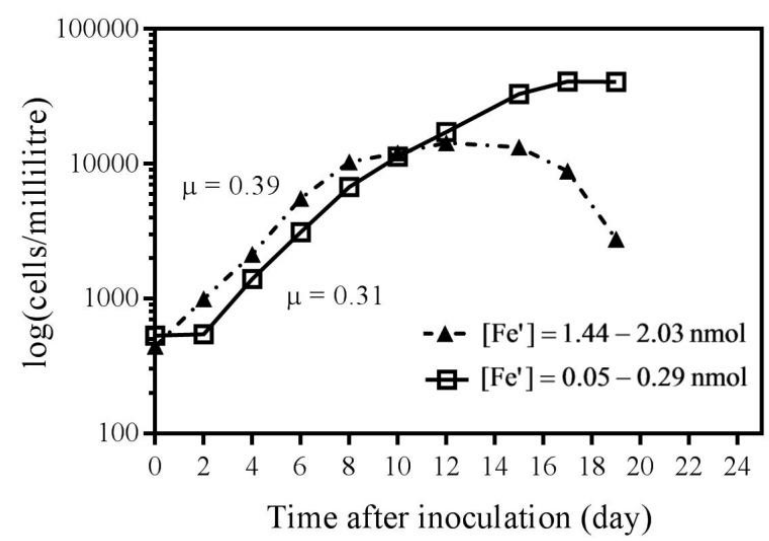

Figure 1. Growth rates of T. erythreum grown in batch cultures with different concentrations of unchelated Fe. Growth rates $\left(\mu\right.$, in units of $\left.\mathrm{d}^{-1}\right)$ were calculated based on the slope from linear regression of $\log$ (cell density) against time for each culture during exponential phase (i.e. days 2-8 for the culture shown as triangles and days 2-15 for the culture shown as squares; see Sect. S1.2 for details) and are annotated on the plot for each curve.

\section{2 $\mathrm{Fe}$ (II) oxidation kinetics in the absence of organic exudates}

The formation of $\mathrm{Fe}(\mathrm{II})$-EDTA complexes has previously been observed to accelerate $\mathrm{Fe}$ (II) oxidation in seawater (Santana-Casiano et al., 2000). This may result from a higher propensity for $\mathrm{O}_{2}$ to react with $\mathrm{Fe}$ (II)L complexes rather than inorganic $\mathrm{Fe}(\mathrm{II})$ (Voelker and Sulzberger, 1996). Consistent with this, we observed a significant difference $(p \leq 0.01)$ between the slope of $\log ([\mathrm{Fe}(\mathrm{II})]$ ) vs time (over the period 110-530 s) in the presence of varying EDTA concentrations in artificial seawater $\left(0,0.05\right.$ and $\left.20 \mu \mathrm{mol} \mathrm{L}^{-1}\right)$ using a general one-way analysis of variance (ANOVA) (Fig. 2). However, due to use of much lower EDTA concentrations in this study, and differences between the ionic strength of the media used, a lesser influence of EDTA on Fe(II) oxidation rate was observed compared to that reported by Santana-Casiano et al. (2000). ANOVA additionally revealed no significant $(p \geq 0.5)$ difference in the slope of $\log ([\mathrm{Fe}(\mathrm{II})])$ vs time during the first (110-170 s) and last (480-530 s) 60 seconds of data within each treatment, indicating Fe(II) oxidation obeyed pseudo-first order kinetics in the media in the absence of organic exudates. 


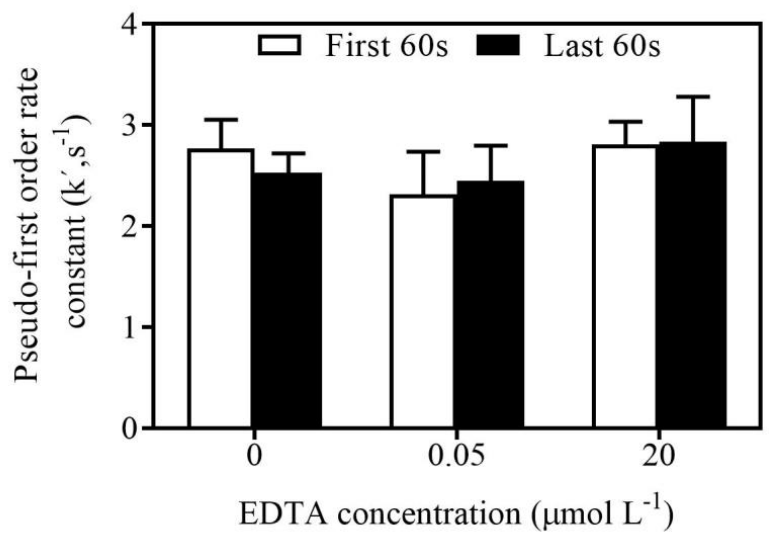

Figure 2. Comparison of apparent pseudo-first order rate constants for $\mathrm{Fe}$ (II) oxidation obtained from the first and the last $60 \mathrm{~s}$ of measurement for ASW containing different EDTA concentrations. Error bars represent the standard deviation of four replicates.

To explore the potential impact of ligands on Fe(II) oxidation kinetics, the oxidation of nanomolar concentrations of added $\mathrm{Fe}$ (II) in ASW was modelled in both the presence and the absence of EDTA (Fig. 3a). As previously stated, the reaction of $\mathrm{Fe}(\mathrm{II})$ with oxygen $\left(\mathrm{O}_{2}\right)$ was the only oxidation reaction considered and the potential back reaction of $\mathrm{Fe}(\mathrm{III}) / \mathrm{Fe}(\mathrm{III}) \mathrm{L}$ with $\mathrm{O}_{2}^{--}$was ignored. Based on kinetic modelling, the second order oxidation rate constant for oxidation of inorganic $\mathrm{Fe}$ (II) over a range of initial $\mathrm{Fe}(\mathrm{II})$ concentrations $(5,10$ and $20 \mathrm{nmol} \mathrm{L}$ ${ }^{1}$ ) was determined to be $5.94 \pm 0.03 \mathrm{M}^{-1} \mathrm{~s}^{-1}$ the physicochemical conditions described in Sect. 2.3 , which is in agreement with values reported in previous studies ranging from 2.2 to $8.5 \mathrm{M}^{-}$ ${ }^{1} \mathrm{~s}^{-1}$ (Millero, 1987;Murray and Gill, 1978; Waite and Morel, 1984). This value of the inorganic $\mathrm{Fe}$ (II) oxidation rate constant in ASW was subsequently used for modelling of $\mathrm{Fe}$ (II) oxidation in the presence of EDTA and organic exudates.

Given that EDTA is known to form complexes with Fe(II) that accelerate Fe(II) oxidation, the observation of pseudo-first order $\mathrm{Fe}$ (II) oxidation kinetics in the presence of EDTA (based on the model fit to the data, Fig. 3b and Fig. 3c) implies that the reaction mechanism involves either rapid complex formation then rate limiting oxidation of the complex, or rate limiting complex formation followed by rapid oxidation of the complex (Rose and Waite, 2003). Since both formation and oxidation rate constants for the Fe(II)EDTA complex were unknown and could not be independently constrained under our experimental conditions due to use of relatively low EDTA concentrations, the oxidation rate constant value was obtained from the literature. Previously, Fujii et al. (2010b) and Santana-Casiano et al. (2000) have determined values of $12 \mathrm{M}^{-1} \mathrm{~s}^{-1}$ and $70.6 \mathrm{M}^{-1} \mathrm{~s}^{-1}$, respectively, for the oxidation rate constant of Fe(II)EDTA in seawater, implying that oxidation of the Fe(II)EDTA complex occurs on a timescale of several minutes and therefore suggesting that the oxidation step is rate limiting and complex formation is rapid. Given that the ionic strength in the latter study was much greater than that used in this study, the Fe(II)EDTA oxidation rate constant reported by Fujii et al. (2010) was used here for modelling purposes. There is little information about the kinetics of formation 
Biogeosciences Discuss., doi:10.5194/bg-2017-129, 2017

Manuscript under review for journal Biogeosciences

Discussion started: 19 May 2017

(c) Author(s) 2017. CC-BY 3.0 License.

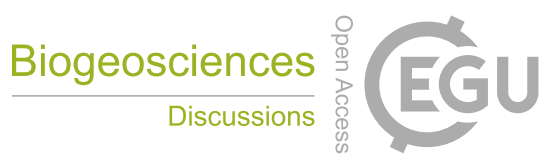

(c) (i)

333 and dissociation of Fe(II)EDTA in artificial seawater (Santana-Casiano et al., 2000). However,

334 assuming that Fe(II)EDTA complexation and dissociation occur rapidly on the timescale of the

$335 \mathrm{Fe}(\mathrm{II})$ oxidation experiments at an EDTA concentration of $20 \mu \mathrm{mol} \mathrm{L}^{-1}$ (i.e. highest [EDTA]

336 used in this study), the dissociation rate constant $k_{\mathrm{d}}$ was arbitrarily set to a value of $1000 \mathrm{~s}^{-1}$

337 and the complex formation rate constant $k_{\mathrm{f}}$ was fitted to the data. On this basis, an apparent

338 stability constant $\left(K=k_{\mathrm{f}} / k_{\mathrm{d}}\right)$ of $16200 \mathrm{M}^{-1}$ was obtained for Fe(II)EDTA in ASW at pH 8.0

339 and $20 \pm 1^{\circ} \mathrm{C}$.

340 
Biogeosciences Discuss., doi:10.5194/bg-2017-129, 2017

Manuscript under review for journal Biogeosciences

Discussion started: 19 May 2017

(C) Author(s) 2017. CC-BY 3.0 License.
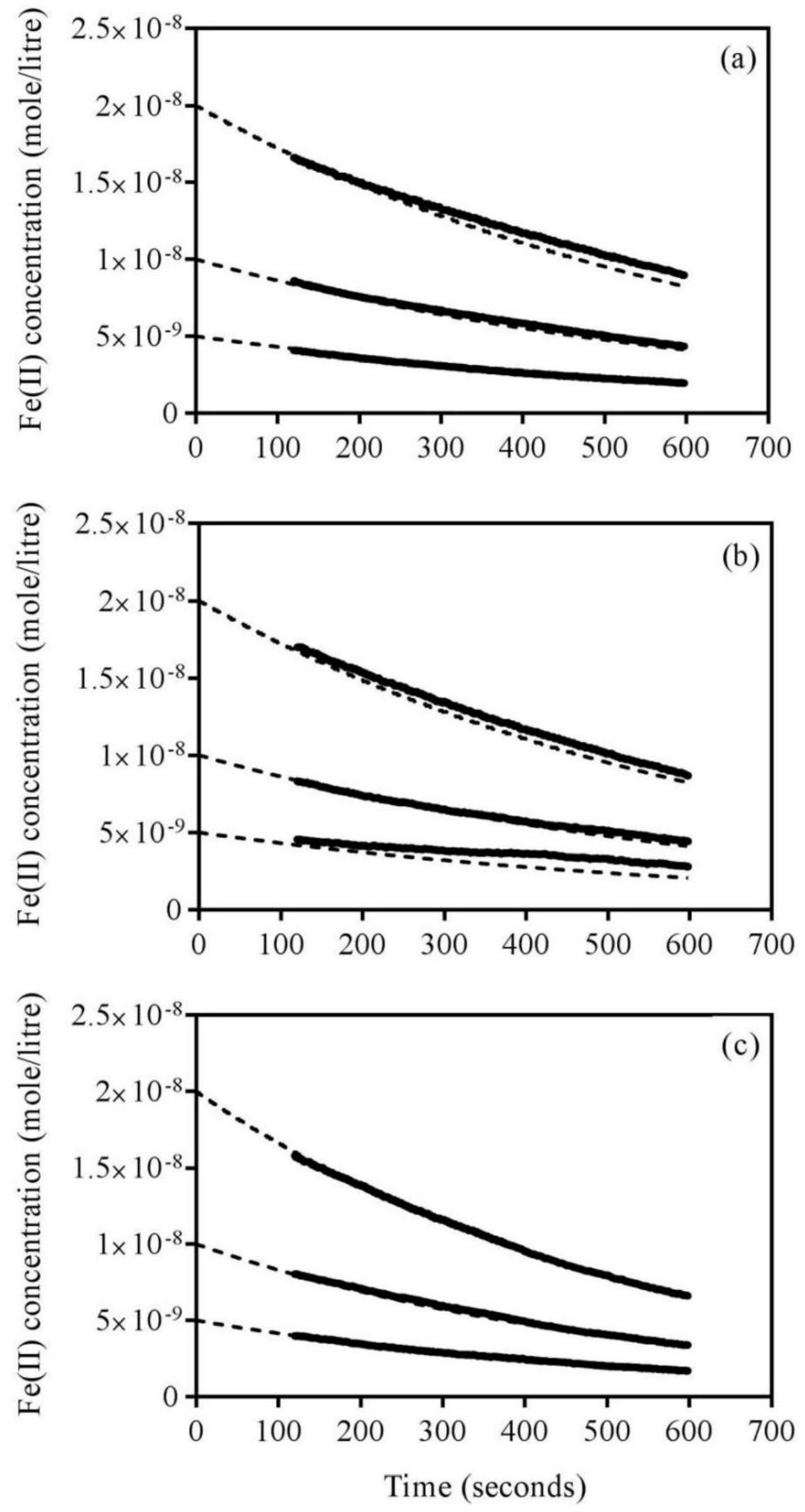

342 Figure 3. Oxidation of Fe(II) in ASW containing (a) no EDTA, (b) $50 \mathrm{nmol} \mathrm{L}^{-1}$ EDTA and (c) $34320 \mu \mathrm{mol} \mathrm{L}^{-1}$ of EDTA in the absence of organic exudates. Data points represent the mean from 344 two measurements and dashed lines indicate the fit of the kinetic model to the data. Initial $345 \mathrm{Fe}(\mathrm{II})$ concentrations were 5, 10 and $20 \mathrm{nmol} \mathrm{L}^{-1}$. Further details on rate constants are provided 346 in Table S1. 
Biogeosciences Discuss., doi:10.5194/bg-2017-129, 2017

Manuscript under review for journal Biogeosciences

Discussion started: 19 May 2017

(c) Author(s) 2017. CC-BY 3.0 License.

\section{3 $\mathrm{Fe}$ (II) oxidation kinetics in the presence of organic exudates}

$\mathrm{Fe}$ (II) oxidation data in the presence of organic exudates from IMS101 cultures were initially fitted by linear regression of $\log ([\mathrm{Fe}(\mathrm{II})])$ against time, assuming pseudo-first order oxidation kinetics. Pearson correlation coefficient values of $r \geq 0.98$ were obtained from all linear regression fits to $\mathrm{Fe}$ (II) oxidation data throughout the entire growth phase of the cultures, suggesting that this approach based on the assumption of pseudo-first kinetics was reasonable. $\mathrm{Fe}(\mathrm{II})$ oxidation was accelerated in the presence of IMS101 exudates from exponentially growing cells under Fe limited conditions, as demonstrated by increasing values of the overall pseudo first order rate constant for $\mathrm{Fe}$ (II) oxidation in culture filtrates compared to the media (Fig. 4). Acceleration of $\mathrm{Fe}(\mathrm{II})$ oxidation in the presence of specific types of organic matter (mostly of terrestrial origin) has been previously noted in several other studies (Millero et al., 1987; Rose and Waite, 2002, 2003;Santana-Casiano et al., 2000).
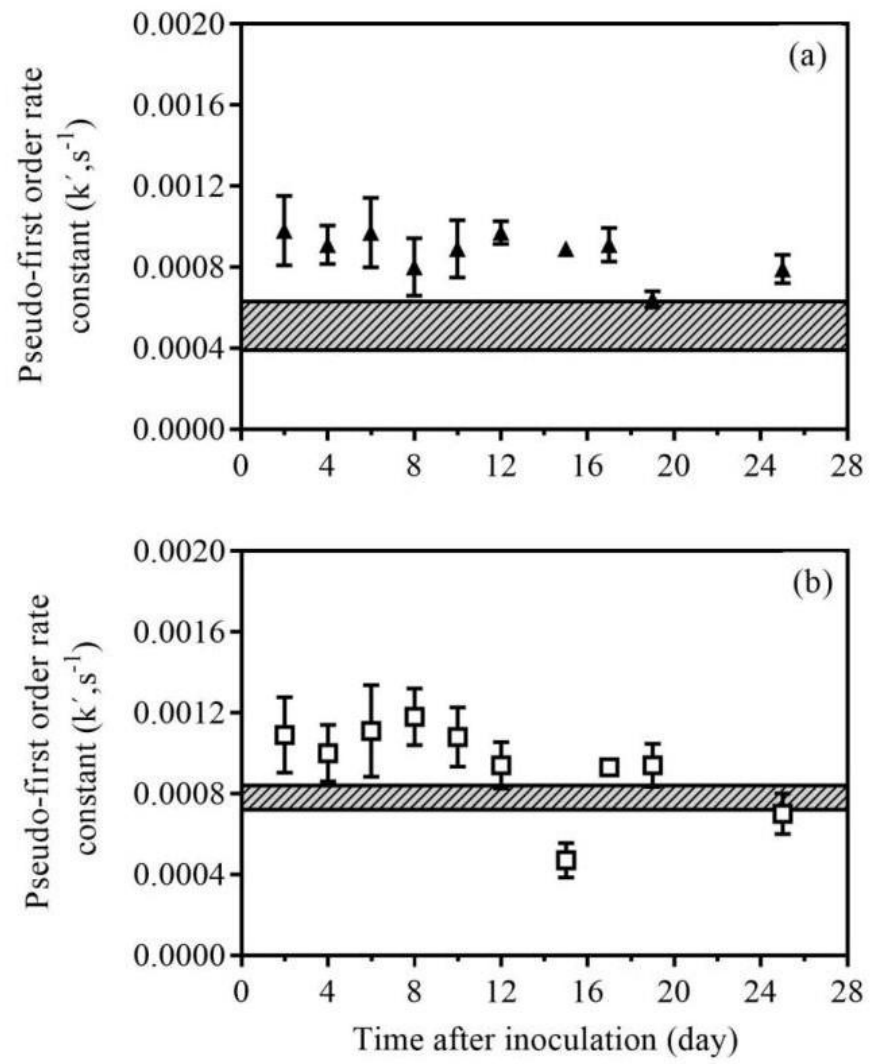

Figure 4. Changes in the apparent pseudo-first order rate constant for $\mathrm{Fe}$ (II) oxidation in filtrate from batch cultures of T. erythraeum grown with (a) $1.44-2.03 \mathrm{nmol} \mathrm{L}^{-1}$ and (b) $0.05-0.29 \mathrm{nmol}$ $\mathrm{L}^{-1} \mathrm{Fe}^{\prime}$ concentrations at different times during the growth cycle of the culture. The shaded area shows the range of measured values of the Fe(II) oxidation rate constant in ASW containing the same nutrient and EDTA concentrations as filtrates in the absence of cells. Symbols represent the mean and error bars represent the standard deviation of the mean from four replicates. Values of oxidation rate constants are reported in Table S1. 
To investigate the assumption pseudo-first order kinetics in more detail, a kinetic model was developed in Kintek Explorer that accounted for the parallel oxidation of inorganic $\mathrm{Fe}(\mathrm{II})$, $\mathrm{Fe}$ (II)EDTA complexes, and a single organic complex between Fe(II) and ligands in the culture exudate. Since concentration of organic ligands in the exudate ([L]) was unknown, the kinetic model was developed based on the assumptions that the ligand is present at a much higher concentration than $\mathrm{Fe}$ (II) (which would be necessary for pseudo-first order kinetics over the entire range of $\mathrm{Fe}(\mathrm{II})$ concentrations examined), that $\mathrm{Fe}(\mathrm{II}) \mathrm{L}$ complexation occurred rapidly compared to $\mathrm{Fe}(\mathrm{II})$ oxidation, and that $\mathrm{Fe}(\mathrm{II}) \mathrm{L}$ dissociation was negligible on the timescale of the $\mathrm{Fe}(\mathrm{II})$ oxidation measurements $\left(k_{\mathrm{d}}=0\right)$. The alternative possibility that $\mathrm{Fe}(\mathrm{II}) \mathrm{L}$ oxidation was very rapid was also investigated. These alternatives correspond to the two most likely possible limiting scenarios under which oxidation would be pseudo-first order (Rose and Waite, 2003). In both cases, the ligand concentration was thus arbitrarily assumed to be $1 \mu \mathrm{mol}$ $\mathrm{L}^{-1}$ then either the rate constant for oxidation of the complex, $k_{\mathrm{ox}}$, was set to an arbitrarily large value and $k_{\mathrm{f}}$ fitted, or $k_{\mathrm{f}}$ was set to an arbitrarily large value and $k_{\mathrm{ox}}$ fitted. In both cases, the model fit to the data was comparable and did not suggest any reason to reject the assumption of pseudo-first order kinetics. Given that it was not possible to distinguish which of the scenarios was most reasonable in reality, and that the actual ligand concentration was also unable to be determined from this approach, no further analysis was undertaken using detailed kinetic modelling.

If we assume that oxidation is rate limiting, however, then $k_{\mathrm{ox}}$ is approximately equal to the overall apparent second-order rate constant for Fe(II) oxidation, $k_{\text {app }}$, enabling comparison with previously reported values of $k_{\text {app. }}$. Under this assumption, an average second order rate constant of $9.60 \pm 1.97 \mathrm{M}^{-1} \mathrm{~s}^{-1}$ for $k_{\mathrm{ox}}$ was calculated from the model fits to the data during exponential phase, given that statistical analysis revealed no significant difference $(p>0.97)$ between the rate constants for actively growing cultures between days 2-8 and 2-15 at ranges 1.44-2.03 and 0.05-0.29 $\mathrm{nmol} \mathrm{L}{ }^{-1} \mathrm{Fe}^{\prime}$ concentrations, respectively. In comparison, several studies have reported a decrease in $\mathrm{Fe}$ (II) oxidation rate in the presence of organic exudates released by some eukaryotic algae. For instance, Santana-Casiano et al. (2014) and Gonzalez et al. (2014) reported apparent second-order Fe(II) oxidation rate constants ( $k_{\mathrm{app}}$ ) of $1.09 \mathrm{M}^{-1} \mathrm{~s}^{-1}$ and $6.9 \mathrm{M}^{-}$ ${ }^{1} \mathrm{~s}^{-1}$ in filtrates from cultures of Phaeodactylum tricornutum and Dunaliella tertiolecta, respectively. In these studies, however, the value of $k_{\text {app }}$ in the seawater used $\left(17.4 \mathrm{M}^{-1} \mathrm{~s}^{-1}\right)$ was much higher than that reported here due to the differences in ionic strength and composition (e.g. silicate or chloride), temperature and dissolved oxygen concentration, resulting in a much greater apparent effect of exudates on Fe(II) oxidation compared to in the absence of exudates. The results presented in this study suggest that Trichodesmium produces a different class of dissolved organic matter which enhances $\mathrm{Fe}(\mathrm{II})$ oxidation. According to Marcus theory (Marcus, 1964), which applies in the case of outer-sphere electron transfer from $\mathrm{O}_{2}$ to $\mathrm{Fe}(\mathrm{II}) / \mathrm{Fe}(\mathrm{II}) \mathrm{L}$ during the oxidation process, the rate of electron transfer between $\mathrm{O}_{2}$ and $\mathrm{Fe}(\mathrm{II}) \mathrm{L}$ is proportional to the ratio of the stability constants (thermodynamic formation constants) for $\mathrm{Fe}(\mathrm{III}) \mathrm{L}$ and $\mathrm{Fe}(\mathrm{II}) \mathrm{L}$ complexes. Therefore, the observed increase in $k_{\mathrm{ox}}$ values for organically complexed $\mathrm{Fe}$ (II) compared to the $k_{\text {ox }}$ value for inorganic $\mathrm{Fe}(\mathrm{II})$ implies that the organic exudates released by T. erythraeum IMS101 likely form more stable complexes with Fe(III) than $\mathrm{Fe}(\mathrm{II})$. The observation of pseudo-first order reaction kinetics and similar oxidation rate 
Biogeosciences Discuss., doi:10.5194/bg-2017-129, 2017

Manuscript under review for journal Biogeosciences

Discussion started: 19 May 2017

(C) Author(s) 2017. CC-BY 3.0 License.

constants for the cultures grown with different Fe' concentrations furthermore suggest that the effect of exudates on $\mathrm{Fe}$ (II) oxidation was likely due to formation of a single type of $\mathrm{Fe}$ (II) complex. Moreover, the lower value of $k_{\text {ox }}$ for $\mathrm{Fe}$ (II)L compared to that for $\mathrm{Fe}$ (II)EDTA suggests the presence of a potentially weak class of Fe(III) binding ligand in IMS101 exudates.

\subsection{Effects of growth phase on Fe(II) oxidation kinetics}

The apparent pseudo-first order rate constant for overall Fe(II) oxidation varied with changes in growth rate over the $\sim 25 \mathrm{~d}$ duration of culture growth (Fig. 5). The results showed a significant $(p \leq 0.01)$ difference between oxidation rate constants in the presence and in the absence of organic exudates. The oxidation rate constants were also observed to decrease as the growth rate approached zero when the cultures entered stationary phase.
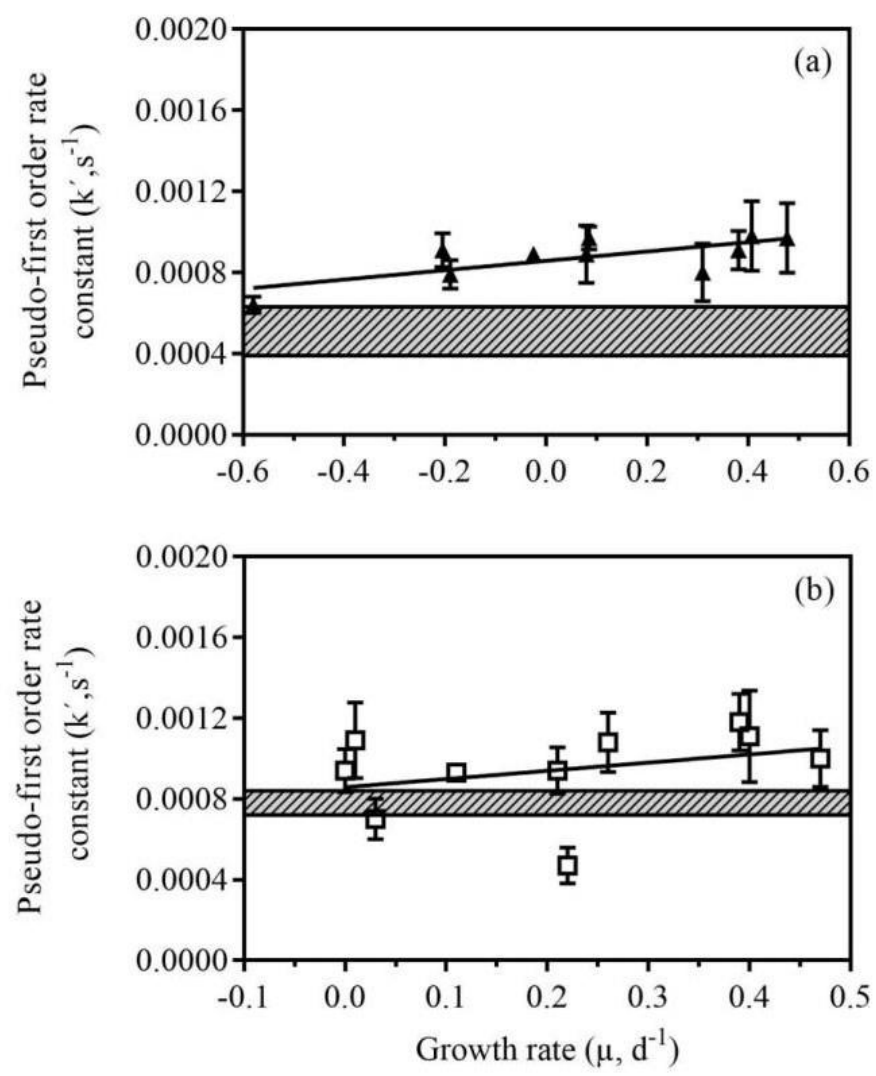

Figure 5. Relationship between growth rate and Fe(II) oxidation rate constant in the culture grown with (a) 1.44-2.03 nmol L-1 and (b) 0.05-0.29 nmol L-1 $\mathrm{Fe}^{\prime}$ concentrations. The shaded area shows the range of measured values of the $\mathrm{Fe}(\mathrm{II})$ oxidation rate constant in ASW containing the same nutrient and EDTA concentrations as filtrates in the absence of cells. Symbols represent the mean and error bars represent the standard deviation of the mean from four replicates. Lines represent linear regression of the data. 
These results are consistent with previous studies implying that exponentially growing cells can actively influence the redox dynamics of $\mathrm{Fe}$ in their surroundings by releasing dissolved organic matter (Gonzalez et al., 2014;Santana-Casiano et al., 2014). This influence cannot be due to the physicochemical conditions under which the experiments were performed (i.e. temperature, $\mathrm{DO}$ and/or $\mathrm{pH}$ ), which were adjusted to maintain similar values in all samples. Fe complexes formed in the presence of exudates may not necessarily be due to complexation by specific Fe binding ligands such as siderophores or porphyrins, as other metabolic products such as carbohydrates and proteins are much more abundant, with abundance often strongly correlated with cell density (Santana-Casiano et al., 2014;Hassler et al., 2011). However, despite an expected increase in DOC concentration towards the end of exponential growth phase, an average (and relatively constant) apparent pseudo first order oxidation rate constant of $0.001 \mathrm{~s}^{-1}$ was observed in both cultures grown with different Fe' concentrations. These findings further support the notion that $T$. erythraeum might exude different organic compounds (Achilles et al. 2003; Hutchins et al. 1999) to diatoms (Gonzalez et al. 2014; Rijkenberg et al. 2008; Steigenberg et al. 2009) and green algae (Gonzalez et al. 2014), and that these exudates may accelerate $\mathrm{Fe}(\mathrm{II})$ oxidation.

\section{Conclusions}

In this study, it was found that $\mathrm{Fe}(\mathrm{II})$ oxidation was accelerated in the presence of organic exudates released by $T$. erythraeum. This occurred to a greater extent when the cells were growing exponentially. Fe(II) oxidation kinetics in the presence of exudates were well described using a pseudo-first order model, implying that the concentrations of organic $\mathrm{Fe}$ binding ligands were much higher than the maximum concentration of Fe(II) added ( $20 \mathrm{nmol}$ $\mathrm{L}^{-1}$ ). This suggests that the ligands most likely complexed $\mathrm{Fe}(\mathrm{II})$ relatively rapidly, with oxidation of the complex being rate limiting in terms of the overall mechanism by which $\mathrm{Fe}$ (II) oxidation was accelerated. Analysis of the kinetics showed that the oxidation rate constants differed significantly depending on the growth phase of the organism in batch culture, with the $\mathrm{Fe}$ (II) oxidation rate declining as the culture approached stationary phase. Moreover, no significant difference was observed between the oxidation rate constants for $\mathrm{Fe}$ (II) in the presence of exudates from the two cultures grown under different $\mathrm{Fe}^{\prime}$ conditions. These results suggest organic complexation of $\mathrm{Fe}$ as a potentially important mechanism which may permit Trichodesmium to facilitate dissolution of solid phase $\mathrm{Fe}$ and therefore increase the solubility of Fe in its surroundings. In addition, observation of an increase in Fe(II) oxidation rates in the presence of organic exudates strengthens the hypothesis for existence of some (probably weak) organic ligands that may complex $\mathrm{Fe}(\mathrm{III})$, followed by reduction or ligand exchange mechanisms at the cell surface. This hypothesis, however, needs to be further tested by more detailed characterisation of the organic matter released by this microorganism.

\section{Author contribution}

Hanieh T. Farid contributed intellectually to the design of all experiments, conducted the experiments, analysed samples, interpreted data, modelling and wrote the manuscript. Andrew L. Rose and Kai G. Schulz contributed intellectually to the experimental design, interpretation of data, and editing process. Andrew L. Rose also contributed to the modelling process. 
Biogeosciences Discuss., doi:10.5194/bg-2017-129, 2017

Manuscript under review for journal Biogeosciences

Discussion started: 19 May 2017

(c) Author(s) 2017. CC-BY 3.0 License.

\section{Competing interests}

The authors declare that they have no conflict of interest.

\section{Data availability}

$\mathrm{Fe}(\mathrm{II})$ oxidation data are publically available from ePublications@SCU (http://epubs.scu.edu.au/).

\section{Acknowledgements}

This work was supported by ARC Discovery Projects DP0558710 and DP120103234 to A.L.R. We thank Tim Walker for his assistance in collecting data during the primary experiments.

\section{References}

Achilles, K. M., Church, T. M., Wilhelm, S. W., Luther, G. W. I., and Hutchins, D. A.: Bioavailability of iron to Trichodesmium colonies in the western subtropical Atlantic Ocean, Limnol. Oceanogr., 48, 2250-2255, 2003.

Andersen, R. A. E.: Algal Culturing Techniques, Elsevier Academic Press, Burlington, MA, 596 pp., 2005.

Benner, R.: Loose ligands and available iron in the ocean, Proceedings of the National Academy of Sciences, 108, 893-894, 2011.

Berman-Frank, I., Cullen, J. T., Shaked, Y., Sherrell, R. M., and Falkowski, P. G.: Iron availability, cellular iron quotas, and nitrogen fixation in Trichodesmium, Limnol. Oceanogr., 46, 1249-1260, 2001.

Berman-Frank, I., Lundgren, P., and Falkowski, P.: Nitrogen fixation and photosynthetic oxygen evolution in cyanobacteria, Res. Microbiol., 154, 157-164, 2003.

Berman-Frank, I., Rosenberg, G., Levitan, O., Haramaty, L., and Mari, X.: Coupling between autocatalytic cell death and transparent exopolymeric particle production in the marine cyanobacterium Trichodesmium, Environmental microbiology, 9, 1415-1422, 2007.

Chappell, P. D., and Webb, E. A.: A molecular assessment of the iron stress response in the two phylogenetic clades of Trichodesmium, Environmental Microbiology, 12, 13-27, 10.1111/j.1462-2920.2009.02026.x, 2010.

Elhabiri, M., Carrër, C., Marmolle, F., and Traboulsi, H.: Complexation of iron (III) by catecholate-type polyphenols, Inorg. Chim. Acta, 360, 353-359, 2007.

Emmenegger, L., King, D. W., Sigg, L., and Sulzberger, B.: Oxidation kinetics of Fe(II) in a eutrophic Swiss lake, Environ. Sci. Technol., 32, 2990-2996, 10.1021/es980207g, 1998.

Falkowski, P. G., Barber, R. T., and Smetacek, V.: Biogeochemical controls and feedbacks on ocean primary production, Science, 281, 200-206, 1998.

Fujii, M., Rose, A. L., Omura, T., and Waite, T. D.: Effect of Fe(II) and Fe(III) transformation kinetics on iron acquisition by a toxic strain of Microcystis aeruginosa, Environ. Sci. Technol., 44, 1980-1986, 10.1021/es901315a, 2010a.

Fujii, M., Rose, A. L., Waite, T. D., and Omura, T.: Oxygen and superoxide-mediated redox kinetics of iron complexed by humic substances in coastal seawater, Environ. Sci. Technol., 44, 9337-9342, 10.1021/es102583c, $2010 \mathrm{~b}$.

Garcia, H. E., and Gordon, L. I.: Oxygen solubility in seawater: Better fitting equations, Limnol. Oceanogr., 37, 1307-1312, 1992.

Garg, S., Rose, A. L., Godrant, A., and Waite, T. D.: Iron uptake by the ichthyotoxic Chattonella marina (Raphidophyceae): impact of superoxide generation, J. Phycol., 43, 978-991, 10.1111/j.1529-8817.2007.00394.x, 2007.

Geider, R. J.: Biological oceanography: complex lessons of iron uptake, Nature, 400, 815-816, 1999. 
Biogeosciences Discuss., doi:10.5194/bg-2017-129, 2017

Manuscript under review for journal Biogeosciences

Discussion started: 19 May 2017

(c) Author(s) 2017. CC-BY 3.0 License.

Godrant, A., Rose, A. L., Sarthou, G., and Waite, T. D.: A new method for the determination of extracellular production of superoxide from phytoplankton cells using MCLA and redCLA as chemiluminescent probes, Limnology and Oceanography: Methods, 7, 682-692, 10.4319/lom.2009.7.682, 2009.

Gonzalez, A. G., Santana-Casiano, J. M., González-Dávila, M., Pérez-Almeida, N., and Suarez de Tangil, M.: Effect of Dunaliella tertiolecta organic exudates on the Fe (II) oxidation kinetics in seawater, Environ. Sci. Technol., 48, 7933-7941, 2014.

Hassler, C. S., Alasonati, E., Mancuso Nichols, C. A., and Slaveykova, V. I.: Exopolysaccharides produced by bacteria isolated from the pelagic Southern Ocean - Role in Fe binding, chemical reactivity, and bioavailability, Mar. Chem., 123, 88-98, 10.1016/j.marchem.2010.10.003, 2011.

Hutchins, D. A., Witter, A. E., Butler, A., and Luther, G. W. I.: Competition among marine phytoplankton for different chelated iron species, Nature, 400, 858-861, 10.1038/23680, 1999.

Ito, Y., and Butler, A.: Structure of synechobactins, new siderophores of the marine cyanobacterium Synechococcus sp. PCC 7002, Limnol. Oceanogr., 50, 1918, 2005.

Jobin, R., and Ghosh, M. M.: Effect of buffer intensity and organic matter on the oxidation of ferrous iron, Journal of the American Water Works Association, 69, 590-595, 1972.

Jones, D. L.: Organic acids in the rhizosphere-a critical review, Plant Soil, 205, 25-44, 1998.

King, D. W., Lounsbury, H. A., and Millero, F. J.: Rates and mechanism of Fe(II) oxidation at nanomolar total iron concentrations, Environ. Sci. Technol., 29, 818-824, 10.1021/es00003a033, 1995.

Kranzler, C., Lis, H., Shaked, Y., and Keren, N.: The role of reduction in iron uptake processes in a unicellular, planktonic cyanobacterium, Environmental Microbiology, 13, 2990-2999, 10.1111/j.1462-2920.2011.02572.x, 2011.

Kustka, A., Sañudo-Wilhelmy, S., Carpenter, E. J., Capone, D. G., and Raven, J. A.: A revised estimate of the iron use efficiency of nitrogen fixation, with special reference to the marine cyanobacterium Trichodesmium spp. (Cyanophyta), J. Phycol., 39, 12-25, 10.1046/j.15298817.2003.01156.x, 2003.

Lewis, E., Wallace, D., and Allison, L. J.: Program developed for $\mathrm{CO} 2$ system calculations, Carbon Dioxide Information Analysis Center, managed by Lockheed Martin Energy Research Corporation for the US Department of Energy Tennessee, 1998.

Liang, L., McNabb, J. A., Paulk, J. M., Gu, B., and McCarthy, J. F.: Kinetics of Fe(II) oxygenation at low partial pressure of oxygen in the presence of natural organic matter, Environ. Sci. Technol., 27, 1864-1870, 10.1021/es00046a014, 1993.

Maldonado, M. T., Allen, A. E., Chong, J. S., Lin, K., Leus, D., Karpenko, N., and Harris, S. L.: Copper-dependent iron transport in coastal and oceanic diatoms, Limnol. Oceanogr., 51, 1729-1743, 2006.

Marcus, R. A.: Chemical and electrochemical electron-transfer theory, Annu. Rev. Phys. Chem., 15, 155-196, 10.1146/annurev.pc.15.100164.001103, 1964.

Miller, C. J., Rose, A. L., and Waite, T. D.: Impact of natural organic matter on $\mathrm{H}_{2} \mathrm{O}_{2}$-mediated oxidation of $\mathrm{Fe}(\mathrm{II})$ in a simulated freshwater system, Geochim. Cosmochim. Acta, 73, 27582768, 10.1016/j.gca.2009.02.027, 2009.

Miller, C. J., Rose, A. L., and Waite, T. D.: Importance of iron complexation for Fentonmediated hydroxyl radical production at circumneutral pH, Frontiers in Marine Science, 3, 134, 2016.

Millero, F. J.: Estimate of the life time of superoxide in seawater, Geochim. Cosmochim. Acta, 51, 351-353, 10.1016/0016-7037(87)90246-8, 1987.

Millero, F. J., Sotolongo, S., and Izaguirre, M.: The oxidation kinetics of Fe(II) in seawater, Geochim. Cosmochim. Acta, 51, 793-801, 10.1016/0016-7037(87)90093-7, 1987. 
Moffett, J. W., and Zafiriou, O. C.: An investigation of hydrogen peroxide chemistry in surface waters of Vineyard Sound with $\mathrm{H}_{2}{ }^{18} \mathrm{O}_{2}$ and ${ }^{18} \mathrm{O}_{2}$, Limnol. Oceanogr., 35, 1221-1229, 1990.

Morel, F. M. M., Kustka, A. B., and Shaked, Y.: The role of unchelated Fe in the iron nutrition of phytoplankton, Limnol. Oceanogr., 53, 400-404, 2008.

Murray, J. W., and Gill, G.: The geochemistry of iron in puget sound, Geochim. Cosmochim. Acta, 42, 9-19, 10.1016/0016-7037(78)90211-9, 1978.

Myklestad, S.: Dissolved Organic Carbon from Phytoplankton, in: Mar. Chem., edited by: Wangersky, P. J., The Handbook of Environmental Chemistry, Springer Berlin Heidelberg, 111-148, 2000.

Nolting, R. F., Gerringa, L. J. A., Swagerman, M. J. W., Timmermans, K. R., and de Baar, H. J. W.: Fe (III) speciation in the high nutrient, low chlorophyll Pacific region of the Southern Ocean, Mar. Chem., 62, 335-352, 10.1016/S0304-4203(98)00046-2, 1998.

Rijkenberg, M. J., Gerringa, L. J., Timmermans, K. R., Fischer, A. C., Kroon, K. J., Buma, A. G., Wolterbeek, B. T., and de Baar, H. J.: Enhancement of the reactive iron pool by marine diatoms, Mar. Chem., 109, 29-44, 2008.

Roe, K. L., Barbeau, K., Mann, E. L., and Haygood, M. G.: Acquisition of iron by Trichodesmium and associated bacteria in culture, Environmental Microbiology, 14, 16811695, 10.1111/j.1462-2920.2011.02653.x, 2012.

Roe, K. L., and Barbeau, K. A.: Uptake mechanisms for inorganic iron and ferric citrate in Trichodesmium erythraeum IMS101, Metallomics, 6, 2042-2051, 2014.

Rose, A. L., and Waite, T. D.: Chemiluminescence of luminol in the presence of iron(II) and oxygen: Oxidation mechanism and implications for its analytical use, Anal. Chem., 73, 5909-5920, 10.1021/ac015547q, 2001.

Rose, A. L., and Waite, T. D.: Kinetic model for Fe(II) oxidation in seawater in the absence and presence of natural organic matter, Environ. Sci. Technol., 36, 433-444, 10.1021/es0109242, 2002.

Rose, A. L., and Waite, T. D.: Effect of dissolved natural organic matter on the kinetics of ferrous iron oxygenation in seawater, Environ. Sci. Technol., 37, 4877-4886, 10.1021/es034152g, 2003.

Rose, A. L.: Iron Acquisition by the Marine Cyanobacterium Lyngbya majuscula, PhD, Civil and Environmental Engineering, The University of New South Wales, Sydney, 2005.

Rose, A. L., Salmon, T. P., Lukondeh, T., Neilan, B. A., and Waite, T. D.: Use of superoxide as an electron shuttle for iron acquisition by the marine cyanobacterium Lyngbya majuscula, Environ. Sci. Technol., 39, 3708-3715, 10.1021/es048766c, 2005.

Rose, A. L.: The influence of extracellular superoxide on iron redox chemistry and bioavailability to aquatic microorganisms, Frontiers in Microbiology, 3, 124, 10.3389/fmicb.2012.00124, 2012.

Rubin, M., Berman-Frank, I., and Shaked, Y.: Dust- and mineral-iron utilization by the marine dinitrogen-fixer Trichodesmium, Nature Geosci, 10.1038/ngeo1181, 2011.

Salmon, T. P., Rose, A. L., Neilan, B. A., and Waite, T. D.: The FeL model of iron acquisition: Nondissociative reduction of ferric complexes in the marine environment, Limnol. Oceanogr., 51, 1744-1754, 10.4319/lo.2006.51.4.1744, 2006.

Santana-Casiano, J., González-Dávila, M., González, A., Rico, M., López, A., and Martel, A.: Characterization of phenolic exudates from Phaeodactylum tricornutum and their effects on the chemistry of Fe (II)-Fe (III), Mar. Chem., 158, 10-16, 2014.

Santana-Casiano, J. M., González-Dávila, M., Rodríguez, M. J., and Millero, F. J.: The effect of organic compounds in the oxidation kinetics of Fe(II), Mar. Chem., 70, 211-222, 10.1016/S0304-4203(00)00027-X, 2000.

Santana-Casiano, J. M., González-Dávila, M., González, A., and Millero, F.: Fe (III) reduction in the presence of catechol in seawater, Aquatic geochemistry, 16, 467-482, 2010. 
Biogeosciences Discuss., doi:10.5194/bg-2017-129, 2017

Manuscript under review for journal Biogeosciences

Discussion started: 19 May 2017

(c) Author(s) 2017. CC-BY 3.0 License.

Schulz, K. G., Zondervan, I., Gerringa, L., Timmermans, K., Veldhuis, M., and Riebesell, U.: Effect of trace metal availability on coccolithophorid calcification, Nature, 430, 673-676, 2004.

616

617

618

619

620

621

622

623

624

625

626

627

628

629

630

631

632

633

634

635

636

637

638

639

640

Shaked, Y., Kustka, A. B., and Morel, F. M. M.: A general kinetic model for iron acquisition by eukaryotic phytoplankton, Limnol. Oceanogr., 50, 872-882, 2005.

Shi, D., Kranz, S. A., Kim, J.-M., and Morel, F. M. M.: Ocean acidification slows nitrogen fixation and growth in the dominant diazotroph Trichodesmium under low-iron conditions, Proceedings of the National Academy of Sciences, 109, E3094-E3100, 10.1073/pnas.1216012109, 2012.

Sohm, J. A., Edwards, B. R., Wilson, B. G., and Webb, E. A.: Constitutive extracellular polysaccharide (EPS) production by specific isolates of Crocosphaera watsonii, Frontiers in microbiology, 2, 2011.

Steigenberger, S., Statham, P. J., Völker, C., and Passow, U.: The role of polysaccharides and diatom exudates in the redox cycling of $\mathrm{Fe}$ and the photoproduction of hydrogen peroxide in coastal seawaters, Biogeosciences, 7, 109-119, 2010.

Sunda, W., Price, N. M., and Morel, F. M. M.: Trace metal ion buffers and their use in culture studies, in: Algal Culturing Techniques, edited by: Andersen, R. A., Elsevier Academic Press, 35-64, 2005.

Voelker, B. M., and Sulzberger, B.: Effects of fulvic acid on Fe (II) oxidation by hydrogen peroxide, Environ. Sci. Technol., 30, 1106-1114, 1996.

Völker, C., and Wolf-Gladrow, D. A.: Physical limits on iron uptake mediated by siderophores or surface reductases, Mar. Chem., 65, 227-244, 10.1016/S0304-4203(99)00004-3, 1999.

Waite, T. D., and Morel, F. M. M.: Coulometric study of the redox dynamics of iron in seawater, Anal. Chem., 56, 787-792, 10.1021/ac00268a045, 1984.

Webb, E. A., Moffett, J. W., and Waterbury, J. B.: Iron stress in open-ocean cyanobacteria (Synechococcus, Trichodesmium, and Crocosphaera spp.): Identification of the IdiA protein, Appl. Environ. Microbiol., 67, 5444-5452, 2001. 